Research Article

\title{
Clinical Study on Effect of Swarnamritaprashana (Modified Swarna Prashana) in the Management of Shayyamutra in Children
}

\author{
Sudheer Sharma', Ajay Rana', Vijaylaxmi Mallanvar ${ }^{3}$
}

${ }^{1}$ Assistant Professor, Department of Kaumarabhritya, Dayanand Ayurvedic College and Hospital, Jalandhar, Punjab, India. ${ }^{2}$ Assistant Professor, Department of Kaumarabhritya, Smt. Urmila Devi Ayurvedic College, Hoshiarpur, Punjab, India. ${ }^{3}$ Associate Professor, Department of PG Studies in Kaumarabhritya, SDM College of Ayurveda BM Road, Thanniruhalla, Hassan, Karnataka, India.

DOI: https://doi.org/10.24321/2394.6547.202006

I $\quad \begin{array}{lllll}\mathbf{N} & \mathbf{F} & \mathbf{O}\end{array}$

Corresponding Author:

Sudheer Sharma, Department of Kaumarabhritya, Dayanand Ayurvedic College and Hospital, Jalandhar, Punjab, India.

E-mail Id:

sonu.sudheer205@gmail.com

Orcid Id:

https://orcid.org/0000-0001-7558-2058

How to cite this article:

Sharma S, Rana A, Mallanvar V. Clinical Study on Effect of Swarnamritaprashana (Modified Swarna Prashana) in the Management of Shayyamutra in Children. J Adv Res Ayur Yoga Unani Sidd Homeo 2020; 7(3\&4): 4-10.

Date of Submission: 2020-12-03

Date of Acceptance: 2020-12-21
$\begin{array}{llllllll}\mathbf{A} & \mathbf{B} & \mathbf{S} & \mathbf{T} & \mathbf{R} & \mathbf{A} & \mathbf{C} & \mathbf{T}\end{array}$

Background: The psychosomatic problems of children vary widely in accordance with many factors, which are responsible for children's physical, mental and emotional progress. In this connection there are so many developmental, behavioral disorders of childhood. Out of them Shayyamutra (enuresis) is the most common messy disorder which is psychosomatic in nature, commonly seen in growing children. Along with other medhya and balya drug it can give better results in Shayyamutra along with Satvavajayachikitsa, that is the reason this study was taken.

Materials and Methods: 40 patients of Shayyamutra satisfying diagnostic criteria and age 6-16 years were selected from outpatient department of Kaumarbhritya, SDM College of Ayurveda and Hospital, Hassan. Among them, 20 patients were treated with swarnamritaprashana capsule daily once for two month along with satvavajaya chikitsa in study group. The other 20 patients were treated with ghrita bharjita Godhuma capsule (placebo) daily once for two month along with satvavajaya chikitsa in control group .The patients were assessed on the completion first month, second month and followed again after third month. It was open labelled standard control non-randomized prospective clinical trial from August 2016 to Feb 2017.

Result: Statistically significant effect $(\mathrm{p}<0.05)$ of swarnamritaprashana capsule along with satvavajaya chikitsa in reduction of all signs and symptoms of nocturnal enuresis after treatment were observed.

Conclusion: Swarnamritaprashana along with satvavajaya chikitsa is effective in reducing the signs and symptoms of Shayyamutra.

Keywords: Swarnamritaprashana Capsule, Satvavajaya Chikitsa, Shayyamutra, Noctural Enuresis 


\section{Introduction}

Bedwetting is one among the common psychosomatic illnesses seen in the school going children due to various reasons. About $7 \%$ of male and $3 \%$ of female children fail to adapt diurnal and nocturnal control of bladder by the age of 4-5 years. ${ }^{1}$

Routine management of nocturnal enuresis involves prescription of medicines like desmopresin, which has lots of limitations as it causes water intoxication and hyponatremia ${ }^{2}$ on a long run, it is not advisable to follow.

Nocturnal enuresis is involuntary passing of urine during sleep, occurring after the age by which bladder control should have been established i.e 4-5 year. However, it is observed that incidence of enuresis is more common in male children than female children with ratio of 3:1. Medical intervention is required if bedwetting persists beyond the age of 5 years. However, factors like psychology, delayed development of bladder control capacity and improper toilet training should also be kept in mind. ${ }^{3}$

Children with Nocturnal enuresis approach Ayurveda physicians for the better treatment. It is treated as Shayyamutra in Ayurveda. The word Shayyamutra denotes, "A child unknowingly passing urine during sleep at night due to the influence of doshik factors." ${ }^{4}$ As per Ayurveda, the treatment for it is to attain neurological maturity and attainment of bladder control.

Swarnaprashana is a formulation described by Acharya Kashyapa. It contains Swarna, Madhu, and Ghrita. Swarnamritaprashana, an indigenous preparation which is modified form of Swarnaprashana is in practice by various practitioners and institutions. ${ }^{5}$ Through professional experience, by using it, good results are seen in Shayyamutra. As Swarnamritaprashana is a gold containing preparation, Swarna is neurotonic and it is Medhavardhaka, Balakara, Ayushya etc. qualities and it is proved to be one among the the best Medhya Rasayna. The Medhya Grita used in the preparation of Swarnamritaprashana contains Brahmi, Shankhapushpi, Vacha, Jatamamsi and Yashtimadhu having Medya, Rasayana and Smritikarka etc properties. ${ }^{6}$ Professional experience has shown that Swarnamritaprashana is effective in children with Shayyamutra. To give a scientific basis to this, this reseach work was taken to evaluate the effect of Swarnamritaprashna in Shayyamutra.

\section{Objectives of Study}

- To study the effect of Swarnamritaprashana on Shayyamutra in children

- To study the effect of Satvavajaya chikitsa on Shayyamutra

- To compare the effect of Swarnamritaprashana and Satvavajaya chikitsa on Shayyamutra

\section{Materials and Methods}

Ethical clearance was obtained from the Institutional Ethics Committee (IEC) of SDM College of ayurveda Hassan, Karnataka (IEC No: SDM/IEC/55/2014-2015).

Duration of Study: From August 2016 to Feb 2017

Source of Data: Children attending OPD of Kaumarabhritya at Sri Dhramsthala Manjunatheshwara College of Ayurveda and Hospital, Hassan.

\section{Diagnostic Criteria}

Children above 5 years having complaints of bedwetting, twice a week for 3 consecutive months.

\section{Inclusion Criteria}

- Children of age group 6-16 yrs presented with nocturnal enuresis irrespective of gender, religion and socioeconomic status were selected

- Those parents who were ready to sign informed consent form

\section{Exclusion Criteria}

- Children who suffered from any systemic disorder like UTI, DM, diagnosed cases of bladder incapacity

- Congenital anomalies like neural tube defect, neurogenic bladder, obstructive uropathy

- Neurological disorders like developmental delay, cerebral palsy, mental retardation

\section{Sampling}

Study Design: The current study was open labelled standard control non-randomized prospective clinical trial.

Sampling Method: 40 children who fulfilled the inclusion exclusion and diagnostic criteria, were selected and allotted into two groups.

\section{Study Group}

20Subjects received 1 soft gel capsule of Swarnamritaprashana, (equivalent to $2 \mathrm{mg}$ of swarnabhasma) once in night time after food, with luke warm water for a period of 2 months along with satvavajaya chikitsa. (Standard psychological intervention mention for nocturnal enuresis including parent counselling, child counselling bladder strengthening exercises).

\section{Control Group}

Children in control group received 1 placebo capsule of bharjita ghodhuma powder once in night time after food, with luke warm water for a period of 2 months along with satvavajya treatment. Children in both the groups undergone urine tests, to rule out UTI, and juvenile diabetes mellitus. Both the group children received de-worming before starting the study. Children in both groups were evaluated once in a month, during the course of treatment 
and one month after the completion of study period.

\section{Preparation of Medicine}

Swarnamritaprashana was prepared in the teaching pharmacy of SDM College of Ayurveda \& Hospital and soft gel capsules were prepared in a in an Ayurvedic facility in Thrissur, Kerala.

\section{Ingredients of Swarnamritaprashana}

- Swarna bhasma

- Guduchi Kashaya

- Brahmi Churna

- Vacha Churna

- Jatamamsi

- Ashvagandha

- Shankhapushpi

- Yashti

- Pippali

- MurchitaGhrita

- Madhu

\section{Dose}

1 soft gel capsule of swarnamritaprashana (equivalent to $2 \mathrm{mg}$ of swarna bhasma).

Duration of Treatment: 2 months.

\section{Criteria of Assessment}

Patients of Shayyamutra in the present study were assessed on the following criteria with different grading.

- $\quad$ Bed wetting frequency

- Withholding time

- Urgency of micturition

- Awakening to use toilet during nights

Follow up: Children were followed for one month after the completion of the study.

\section{Laboratory Investigations}

\section{Routine Urine Analysis}

- Urine sugar: by Benedict's qualitative test method

- Albumin: By glacial acetic acid test method

- Microscopic

\section{Criteria of Assessment of Effects}

\section{Bed Wetting Frequency}

The severity of bed wetting has been ascribed a scoring as:

- More than 3 times per day - 8

- Daily if more than one time - 7

- Daily if done - 6

- If on Alternative days - 5

- If weakly twice - 4

- Ones in a week - 3

- Ones in a fortnight - 2
- Ones in a month - 1

- $\quad$ All dry nights - 0

\section{Withholding Time}

- Able to withhold the full bladder $<1$ min - 3

- Able to withhold the full bladder 1 - 2 min - 2

- Able to withhold the full bladder 2 - 3min - 1

- Able to withhold the full bladder $>3 \min -0$

Awakening to Use Toilet during Night

- Never awakens spontaneously - 3

- Self-awakens due to wetness - 2

- $\quad$ Self-awakens due to little passage of urine - 1

- Self-awakens when bladder is full - 0

\section{Urgency of Micturition}

- Reflex is uncontrollable - 2

- Reflex is controllable for shorter duration (<4 minutes)1

- Reflex is controllable for longer duration (>4 minutes)- 0

\section{Result}

40 patients were registered for this study out of which 20 patients were in study group and 20 patients were in placebo group, four patients from study group and four patients from placebo group didn't completed the treatment. Patients of the both groups also received counselling simultaneously. The results obtained in both the groups are being described here under separate headings.

First, we will discuss effect of treatment within the group:

\section{Effect on Bedwetting Frequency \\ Study Group}

In this group, there was significant improvement seen in bedwetting frequency in first month $(P<0.001)$, in second month $(P<0.001)$, on follow up after one month $(P<0.002)$ and also there was significant result between before treatment and follow up $(\mathrm{P}<0.001)$.

\section{Control Group}

In this group, there was significant improvement seen after first month $(P<0.004)$ and in second month $(P<0.002)$ but there was non-significant improvement seen on follow up $(P<0.317)$, but overall there was significant improvement between before treatment and follow up $(P<0.001)$.

\section{Effect on Withholding Time}

\section{Study Group}

In this group, there was significant improvement seen after first month $(P<0.005)$ again there was significant improvement in second month $(\mathrm{P}<0.003)$ but non-significant improvement on follow up $(P<0.317)$ but overall there was significant result between before treatment and follow up $(\mathrm{P}<0.001)$. 


\section{Control Group}

In this group, there was significant improvement seen after first month $(<0.046)$, in second month $(<0.008)$ but there was non-significant improvement on follow up $(\mathrm{P}<1.000)$ and overall there is significant improvement between before treatment and follow up $(\mathrm{P}<0.001)$.

\section{Effect on Urgency of Micturation}

\section{Study Group}

In this group, there was non-significant improvement after first month $(P<0.157)$ but there was significant improvement in second month $(P<0.001)$ again there was non-significant improvement on follow up $(P<0.157)$ but finally there was significant result between before treatment and follow up $(P<0.001)$.

\section{Control Group}

In this group, there was non-significant improvement after first month $(P<1.000)$ but there was significant improvement in second month $(P<0.002)$ again there was non-significant improvement on follow up $(\mathrm{P}<1.000)$ but finally there was significant improvement between before treatment and follow up $(\mathrm{P}<0.002)$.

\section{Effect on Awakening after Evacuation}

\section{Study Group}

In this group, there was significant improvement after first month $(P<0.00)$, after second month $(P<0.001)$; again, there was significant improvement seen after follow up $(P<0.034)$, and overall there was significant improvement between before treatment and follow up $(P<0.001)$.

\section{Control Group}

In this group, there was non-significant improvement after all three months $(P<0.157),(P<0.083),(P<0.157)$ but there was significant improvement between before and after treatment $(P<.020)$.

\section{Effect of Treatment Between the Groups}

For comparison of the difference between mean ranks of two groups, Mann-Whitney $U$ test was applied.

For comparison of the difference in change in bedwetting frequency between the groups, Mann-Whitney $U$ test was applied, it was assessed to see the mean difference. On running the Mann-Whitney $U$ test, it was seen that nonsignificant improvement was present between the groups at first month $p$ value $<0.051$, but, in the second month, it showed significant difference $<0.001$, same way in the third month it showed significant difference $<0.001$ (Table 1).

On running the Mann-Whitney $U$ test, it was seen that non-significant difference was present between the groups at first month $p$-value $<0.162$ but in the second month it showed significant difference $<0.001$, same way in the third month it showed significant difference $<0.003$ (Table 2).

On running the Mann-Whitney $U$ test, it was seen that nonsignificant difference was present between the groups at first month $p$-value $<0.325$, in the second month also, it showed non-significant difference $<0.246$, but in the third month it showed significant difference $<0.035$ Table 3).

For comparison of the difference in change in bedwetting frequency between the groups, Mann-Whitney $U$ test was applied, it was assessed to see the mean difference. On running the Mann-Whitney $U$ test, it was seen that significant difference was present between the groups at first month $p$-value $<0.001$, in the second month also it showed significant difference $<0.001$, same way in the third month it showed significant difference $<0.001$ (Table 4).

Table I.Effect on bedwetting frequency between the groups

\begin{tabular}{|c|c|c|c|c|c|c|c|}
\hline Parameter & Groups & $\mathbf{N}$ & MR & SR & $\mathrm{x} 2$ & p-value & Remark \\
\hline \multirow{3}{*}{ Bedwetting frequency BT } & Study & 16 & 17.44 & 279.00 & \multirow{3}{*}{113.00} & \multirow{3}{*}{.547} & \multirow{3}{*}{ NS } \\
\hline & Control & 16 & 15.56 & 249.00 & & & \\
\hline & Total & 32 & & & & & \\
\hline \multirow{3}{*}{ after one month } & Study & 16 & 13.50 & 216.00 & \multirow{3}{*}{80.00} & \multirow{3}{*}{.051} & \multirow{3}{*}{ NS } \\
\hline & Control & 16 & 19.50 & 312.00 & & & \\
\hline & Total & 32 & & & & & \\
\hline \multirow{3}{*}{ after two month } & Study & 16 & 10.19 & 163.00 & \multirow{3}{*}{27.00} & \multirow{3}{*}{.001} & \multirow{3}{*}{$S$} \\
\hline & Control & 16 & 22.81 & 365.00 & & & \\
\hline & Total & 32 & & & & & \\
\hline \multirow{3}{*}{ after three month } & Study & 16 & 9.06 & 145.00 & \multirow{3}{*}{9.00} & \multirow{3}{*}{.001} & \multirow{3}{*}{$S$} \\
\hline & Control & 16 & 23.94 & 383.00 & & & \\
\hline & Total & 32 & & & & & \\
\hline
\end{tabular}


Table 2.Effect on withholding time between the groups

\begin{tabular}{|c|c|c|c|c|c|c|c|}
\hline Parameter & Groups & $\mathbf{N}$ & MR & SR & $\mathrm{X} 2$ & p-value & Remark \\
\hline \multirow{3}{*}{ Withholding time BT } & Study & 16 & 15.81 & 253.00 & \multirow{3}{*}{117.000} & \multirow{3}{*}{.619} & \multirow{3}{*}{ NS } \\
\hline & Control & 16 & 17.19 & 275.00 & & & \\
\hline & Total & 32 & & & & & \\
\hline \multirow{3}{*}{ after one month } & Study & 16 & 14.47 & 231.50 & \multirow{3}{*}{95.500} & \multirow{3}{*}{.162} & \multirow{3}{*}{ NS } \\
\hline & Control & 16 & 18.53 & 296.50 & & & \\
\hline & Total & 32 & & & & & \\
\hline \multirow{3}{*}{ after two month } & Study & 16 & 13.00 & 208.00 & \multirow{3}{*}{72.00} & \multirow{3}{*}{0.001} & \multirow{3}{*}{$S$} \\
\hline & Control & 16 & 20.00 & 320.00 & & & \\
\hline & Total & 32 & & & & & \\
\hline \multirow{3}{*}{ after three month } & Study & 16 & 12.50 & 200.00 & \multirow{3}{*}{64.000} & \multirow{3}{*}{.003} & \multirow{3}{*}{$S$} \\
\hline & Control & 16 & 20.50 & 328.00 & & & \\
\hline & Total & 32 & & & & & \\
\hline
\end{tabular}

Table 3. Effect on urgency of micturation between the groups

\begin{tabular}{|c|c|c|c|c|c|c|c|}
\hline Parameter & Groups & $\mathbf{N}$ & MR & SR & $\mathrm{X} 2$ & $p$-value & Remark \\
\hline \multirow{3}{*}{$\begin{array}{l}\text { Urgency of micturation } \\
\text { bt }\end{array}$} & Study & 16 & 17.44 & 279.00 & \multirow{3}{*}{113.00} & \multirow{3}{*}{.325} & \multirow{3}{*}{ NS } \\
\hline & Control & 16 & 15.56 & 249.00 & & & \\
\hline & Total & 32 & & & & & \\
\hline \multirow{3}{*}{ after one month } & Study & 16 & 16.50 & 264.00 & \multirow{3}{*}{128.0} & \multirow{3}{*}{1.000} & \multirow{3}{*}{ NS } \\
\hline & Control & 16 & 16.50 & 264.00 & & & \\
\hline & Total & 32 & & & & & \\
\hline \multirow{3}{*}{ after two month } & Study & 16 & 15.00 & 240.00 & \multirow{3}{*}{104.0} & \multirow{3}{*}{.246} & \multirow{3}{*}{ NS } \\
\hline & Control & 16 & 18.00 & 288.00 & & & \\
\hline & Total & 32 & & & & & \\
\hline \multirow{3}{*}{ after three month } & Study & 16 & 14.00 & 224.00 & \multirow{3}{*}{88.0} & \multirow{3}{*}{.035} & \multirow{3}{*}{$S$} \\
\hline & Control & 16 & 19.00 & 304.00 & & & \\
\hline & Total & 32 & & & & & \\
\hline
\end{tabular}

Table 4. Effect on awakening after evacuation between the groups

\begin{tabular}{|c|c|c|c|c|c|c|c|}
\hline Parameter & Groups & N & MR & SR & X2 & p-value & Remark \\
\hline \multirow{4}{*}{$\begin{array}{c}\text { Awakening to use toilet } \\
\text { during night bt }\end{array}$} & Study & 16 & 14.50 & 232.00 & 96.00 & .035 & S \\
\cline { 2 - 8 } & Control & 16 & 18.50 & 296.00 & & & \\
\cline { 2 - 8 } & Total & 32 & & & & & \\
\hline \multirow{3}{*}{$\begin{array}{c}\text { Awakening to use toilet } \\
\text { during night after one month }\end{array}$} & Study & 16 & 10.88 & 174.00 & 38.00 & .001 & $\mathrm{~S}$ \\
\hline & Control & 16 & 22.13 & 354.00 & & & \\
\hline & Total & 32 & & & & & \\
\hline \multirow{3}{*}{$\begin{array}{c}\text { Awakening to use toilet } \\
\text { during night after two month }\end{array}$} & Study & 16 & 9.28 & 148.50 & 12.50 & .001 & $\mathrm{~S}$ \\
\hline & Control & 16 & 23.72 & 379.50 & & & \\
\hline & Total & 32 & & & & & \\
\hline $\begin{array}{c}\text { Awakening to use toilet } \\
\text { during night after three } \\
\text { month }\end{array}$ & Study & 16 & 9.19 & 147.00 & 11.00 & .001 & $\mathrm{~S}$ \\
\hline & Control & 16 & 23.81 & 381.00 & & & \\
\hline & Total & 32 & & & & & \\
\hline
\end{tabular}




\section{Discussion}

\section{Discussion on Selection of Drug}

Though swarnamritaprashanais not directly indicated in the treatment of Shayyamutra, but majority of the drugs in swarnamritaprashana formed to have its action on Manovahasrotasa and having balya, medhya and rasayana properties. These facts substantiate its usage in Shayyamutra. Hence, the drugs was selected.

\section{Discussion on Result}

Bed Wetting Frequency: Both study and control group showed significant relief in bed-wetting $(p<0.001)$ and $(p<0.004)$ after 1 month but more significance in study group, after 2 months of treatment also, study group was found more effective $(p<0.001)$ than that of control group $(p<0.002)$. on follow up also study group showed significant relief $(p<0.002)$ but non-significant relief found in control group $(p<0.317)$.

After the treatment of $1^{\text {st }}$ and $2^{\text {nd }}$ month children of both the groups showed improvement but more significant in study group while at follow up study group showed significant improvement which is very high compared to the control group. The tremendous improvement in the study group may be due to rasayna, medhya and tridoshahara properties of swarnamritaprashana, Swarnamritaprashana has beneficial effect on nervous system, it is very helpful in improving memory, retention power, intelligence and cognitive function. So we can say that swarna along with other medhya and balya drugs in this combination helped in reducing bedwetting frequency more significantly than the control group.

Tinospora cordifolia enhanced the cognition in normal and cognition deficits animals in behavioural test Hebb William maze and the passive avoidance task, which also might have aided in decreasing bedwetting frequency. ${ }^{7}$

Bladder withholding Time: Both study and control group showed significant results in increasing the withholding time during day time urination $(p<0.005)$ and $(p<0.046)$ at $1^{\text {st }}$ month and also at $2^{\text {nd }}$ month $(p<0.003)$ and $(p<0.008)$, more significant in study group But at follow up control group showed non-significant relief $(p<1.000)$.

This may be due to balya property of swarna and ashwagandha and daily practice of different bladder exercises taught to the patient like- the mid stream interruption etc. must have helped.

Ashwagandha improve the neuro-muscular tone and strength and thus increase the retention capacity of urinary bladder which might have helped in Shayyamutra by increasing bladder strength. ${ }^{8}$

Urgency of Micturition: Both study and control group did not show any effect in reducing the urgency of micturition after 1 month of treatment. But after completion of 2 months treatment study group showed more significant improvement in reducing urgency of micturition $(p<0.001)$ than control group $(p<0.002)$, and on follow up also there was non-significant improvement in control group.

The improvement may be because of increased strength of bladder neck sphincters with balya properties of swarna and also ashwagandha and bladder exercises.

Awakening to use toilet in the night: The analysis of the effect on awakening to use toilet in the study group showed significant relief $(p>0.002)$ and non significant relief in control group ( $p<0.157)$ after 1 month of treatment, same result found after 2 nd as well as after 3 rd month ,study group $(<p 0.034)$ and $(p<0.157)$.

After completion of 1st months of treatment improvement is observed in few patients in study group above the age of 8 years. This age group may have some social awareness, shamefulness and can concentrate and practice different techniques better \& try to be more alert during sleep. In study group, there is significant improvement that may be due to combined effect of action of medhya drugs on CNS and uro-genital system and satvavajayachikitsa.

Monnieri has been shown to cause prolonged elevated level of cerebral glutamic acid and a transient increase in GABA level. Endogenous increase in brain glutamine may be helpful in the process of learning, which might have helped in reducing bed wetting frequency and awakening to use toilet by its nootropic effect. ${ }^{9}$

A strong ambition to get rid of this disease, proper toilet training, regular practice of concentration exercise, parental support good counselling by professional counsellor and a potent medicine like swarnamritaprashana help children to get rid of Bed-Wetting.

\section{Mode of Action of Swarnamritaprashana}

Shayyamutra is presumed as a result of emotional conflicts of child's tender mind due to small age or less intelligence to outgrow of these emotional conflicts.

To promote intelligence as well as to support and help the child to overcome the emotional conflicts the medhya drugs which are used in this formulation might had aided.

As the child grows, gold is also being recommended to be given alone or along with various herbal drugs for procuring better Agni (digestive power and metabolism), Bala (physical strength and immunity), Medha (intellect), Varna (colorand complexion), Ayu (lifespan), etc.

Constipation also causes bedwetting, Drugs present in swarnamritaprashana like pippli, brahmi, vacha, jatamamsi, ashwagandha, shankhapushpi had katutikta rasa which 
might act as pachaka and helped in relieving constipation and enuresis.

As drugs like brahmi, jatamamsi, ashwagandha, shankhapushpi and madhu have Kashaya Rasa, hence by means of Kashaya Rasa it does the action of Stambhana on Mutra-Vahasrotas thereby helped in Shayyamutra, Historically one notable use of gold was as a "nervine," a substance that could revitalize people suffering from nervous conditions, what today we would call neurological and psychiatric disorders such as epilepsy and depression, as enuresis is a psychosomatic disorder so swarna might have helped here.

Shankhapushpi is effective in relieving signs and symptoms of Chittodvega (anxiety disorders). Herbalists believe that Shankhpushpi calms the nerves by regulating the body's production of the stress hormones, adrenaline and cortisol. So this way it might have helped in treating secondary enuresis. ${ }^{10}$

\section{Probable Mode of Action of Satvavajaya Chikitsa}

Satvavajaya is that typical approach which not only prevents the impairment of intellect, patience, and memory but also bring them back to a normal state. satvavajay achikitsa uplift the Satva of the children.

Dhyana or meditation as Satvavajaya Chikitsa is discussed in Bhutavidya. Through the practice of meditation or Dhyana, one achieves a state of (1) Emotional stability and (2) A quiet mind, and it will be realized that these practices begin at physiological level with proper control of reflexes (i.e. micturition reflex); it then progresses, through techniques of concentration to progressive control of higher mental process leading to control of mind and thus controls vata.

\section{Conclusion}

On the basis of the overall result, we can say that swarnamritaprashana capsule clubbed with psychological intervened can yield better result.

\section{Conflict of Interest: None}

\section{References}

1. Kliegman RM, Behrman RE, Jenson HB, Stanton BF, Editors. Nelson Textbook of Pediatrics. $18^{\text {th }}$ ed. Philadelphia: Saunders; 2008; 113.

2. Paul VK, bagga A, Editors. Essential Pediatrics. 8thed. New Delhi: Jain; 2013; 504.

3. Shejwal MS, Editor. Clinical Pediatrics for General Practitioners. $1^{\text {st }}$ ed. Hardbound: Bhalani publishing house; 2004; 48.

4. Tripathi Brahmanand. Editor. SarngadharaSamhita, 2nded. Varanasi: Chaukhambaprakashan; 1994; 114.

5. Rao N Prasana, U Shailaja, Mallika KJ, Desai S, Parikshit D. Traditional Use of swarnamrithaPrashana as a preventive measure: Evidance based observational study in children. International Journal of Research in Ayurveda \& Pharmacy 2012; 3(5): 634-638.

6. Sastry JLN. Illustrated Dravyaguna vijanana. 3rded. Varanasi: Chaukhambha orientalia. 2008; 2.

7. Yalla Reddy Y, Mohana Lakshmi S, Saravana KA. Review on Effect of Natural Memory Enhancing Drugs On Dementia. Int J Phytopharmacol 2010; 1: 1-7.

8. Potential medicinal plants for CNS disorders: an overview. Kumar V Phytother Res 2006; 20(12): 10231035.

9. Yalla Reddy Y, Mohana Lakshmi S, Saravana KA. Review on Effect of Natural Memory Enhancing Drugs On Dementia. Int J Phytopharmacol 2010; 1: 1-7.

10. Potential medicinal plants for CNS disorders: an overview. Kumar V Phytother Res 2006; 20(12): 10231035. 